\title{
Male silver eels mature by swimming
}

\author{
Arjan P Palstra1, Denhi Schnabel ${ }^{2}$, Maaike C Nieveen ${ }^{1}$, Herman P Spaink² \\ and Guido EEJM van den Thillart*1
}

\author{
Address: ${ }^{1}$ Integrative Zoology, Institute of Biology, Leiden University (IBL), van der Klaauw Laboratory, Kaiserstraat 63, 2311 GP Leiden, The \\ Netherlands and ${ }^{2}$ Molecular Cell Biology, Institute of Biology, Leiden University (IBL), Clusius Laboratory, 2333 AL Leiden, The Netherlands \\ Email: Arjan P Palstra - a.p.palstra@biology.leidenuniv.nl; Denhi Schnabel - denhi@ibt.unam.mx; \\ Maaike C Nieveen - m.c.nieveen@biology.leidenuniv.nl; Herman P Spaink - h.p.spaink@biology.leidenuniv.nl; Guido EEJM van den \\ Thillart* - g.van.den.thillart@biology.leidenuniv.nl \\ * Corresponding author
}

Published: 10 July 2008

BMC Physiology 2008, 8:14 doi:10.1186/1472-6793-8-14

This article is available from: http://www.biomedcentral.com/l472-6793/8/14

(C) 2008 Palstra et al; licensee BioMed Central Ltd.

This is an Open Access article distributed under the terms of the Creative Commons Attribution License (http://creativecommons.org/licenses/by/2.0), which permits unrestricted use, distribution, and reproduction in any medium, provided the original work is properly cited.
Received: 6 March 2008

Accepted: 10 July 2008

\begin{abstract}
Background: If European silver eels are prevented from reproductive migration, they remain in a prepubertal stage by dopaminergic inhibition of pituitary activity. Because this inhibition is likely a requirement for an extended female growth stage, we tested if it is sex-specific by subjecting both sexes to stimulation by GnRHa (Gonadotropin-Releasing Hormone agonist) - injection or 3months swimming in seawater.
\end{abstract}

Results: In contrast to females, males showed a two- to three-fold higher LH $\beta$ (luteinising hormone $\beta$ subunit) - expression, a three- to five-fold higher GSI (Gonadosomatic index) and induced spermatogenesis when compared with the untreated control group.

Conclusion: Dopaminergic inhibition is thus not effective in males and swimming results in natural maturation, probably via GnRH-release.

\section{Background}

When European silver eels (Anguilla anguilla) venture in the ocean for their 5,500-km semelparous spawning run to the Sargasso Sea [1], they are still in a prepubertal stage. Sexual maturation has thus to occur during or after this long distance journey. Maturation in eels, as in other vertebrates, is regulated by the gonadotropic follicle-stimulating hormone (FSH) and luteinising hormone ( $\mathrm{LH})$ that are produced by the pituitary. If prevented from undertaking their oceanic migration, gonad development remains blocked by dopaminergic inhibition of pituitary activity as well as the absence of stimulation by GonadotropinReleasing Hormone (GnRH) [2]. Information about natural maturation is lacking, because migrating and spawning eels have never been caught near the spawning grounds. There is however an urgent need for an understanding of eel reproduction, because populations are collapsing on a global scale [3].

Investigations on eel reproduction have been mainly focussed on females. They stay $7-30$ years in the freshwater before migration, in contrast to 4-9 years for males. As a consequence, females reach a ten-fold larger size than males at the onset of migration. The long female growth stage is likely required for a successful production of more than one million eggs, which at spawning time accounts for $40-60 \%$ of the body weight [4]. As the energy requirements for males are far less than those for females, it is possible that the observed dopaminergic inhibition is sexspecific. We have tested this hypothesis by subjecting 
male and female eels to a GnRH-agonist (GnRHa), specifically the commercial product Gonazon For Fish (Intervet), as well as to stimulation by long-term swimming in seawater (SW) that is supposed to stimulate GnRH excretion by the hypothalamus. Recently we found that swimming in freshwater (FW) triggers the enlargement of the eyes and development of oocytes in female eels $[5,6]$; all signs of early maturation, suggesting that swimming is a natural trigger for sexual maturation. However, further maturation (e.g. vitellogenesis) was not stimulated by FW-swimming, and may only be stimulated by SW-swimming during natural migration.

\section{Results}

Males that were either stimulated by three months SWswimming or by GnRHa-injection showed a two- to threefold higher LH $\beta$ expression level than the male starters and resters (Fig. 1a). Both treatments also caused a threeto five-fold increase in GSI (Fig. 1b) and an induced spermatogenesis $(>80 \%$ presence of spermatogonia late type b; Fig. 2). One male swimmer even showed the formation

a) male $\mathrm{LH} \beta$

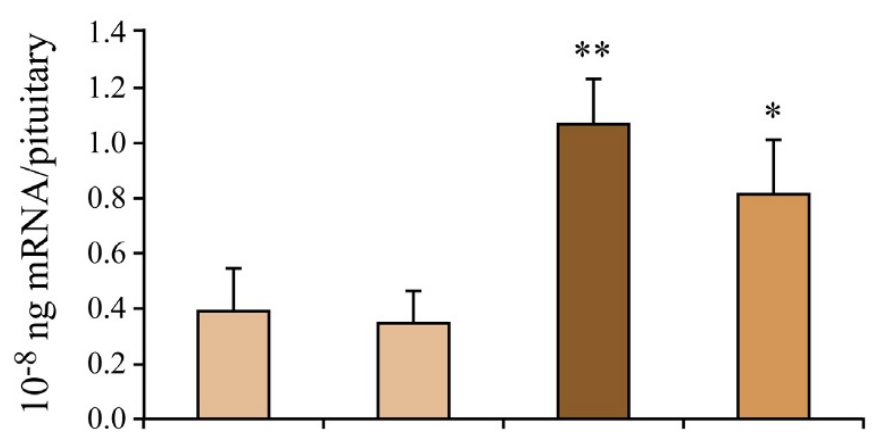

c) male GSI

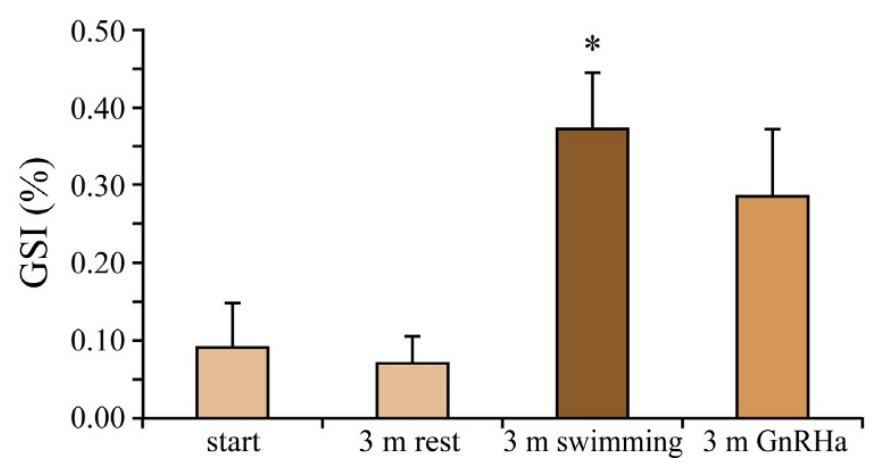

of spermatocytes (Fig. 2). In contrast, females were not stimulated by SW-swimming nor by GnRHa, and even showed regression of maturation over time as demonstrated by lower LH $\beta$ expression (Fig. 1c), GSI (Fig. 1d) and oocyte diameters in all groups after 3 months (Fig. 2). The expression of FSH $\beta$ did not significantly change under the different treatments in both males and females.

\section{Discussion and conclusion}

The results show an obvious difference between male and female eels in their response to both SW-swimming and GnRHa-injection. In female eels, GnRHa is not effective which confirms the conclusions by Dufour et al. [7] about prepubertal inhibition.

In contrast to the response of the females, we observed sexual maturation in males upon GnRHa-injection, indicating that dopaminergic inhibition is not effective in males. In addition we observed stimulation of sexual maturation in male eels after three months SW-swimming, suggesting that swimming acts via a similar mechanism.

b) female $\mathrm{LH} \beta$

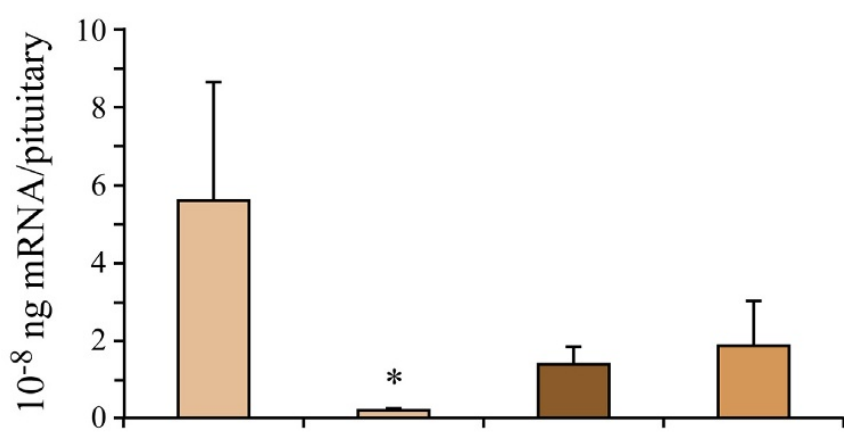

d) female GSI

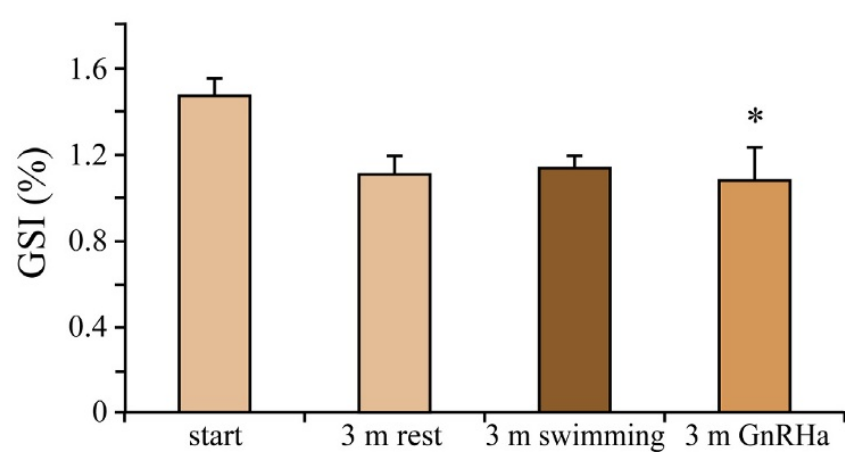

Figure I

Expression (Q-RT-PCR) of luteinising hormone subunit (LH $\beta$ ) in the pituitary and the gonadosomatic index (GSI) in male and female eels. Eels were sampled at the start, after three months rest, after three months of SW-swimming and three months after a single GnRHa injection (Gonazon For Fish, Intervet). In females, regression occurs during the experimental period, an effect which is more pronounced in the resting group than those stimulated by SW-swimming and GnRHa. In males however, SW-swimming and GnRHa activate maturation (student t-tests with $*=P<0.05 ; * *=P<0.01 ; 3 \mathrm{~m}$ rest vs. start, $3 \mathrm{~m}$ swimming or $3 \mathrm{~m}$ GnRHa vs. $3 \mathrm{~m}$ rest). 
a) female oocyte diameter

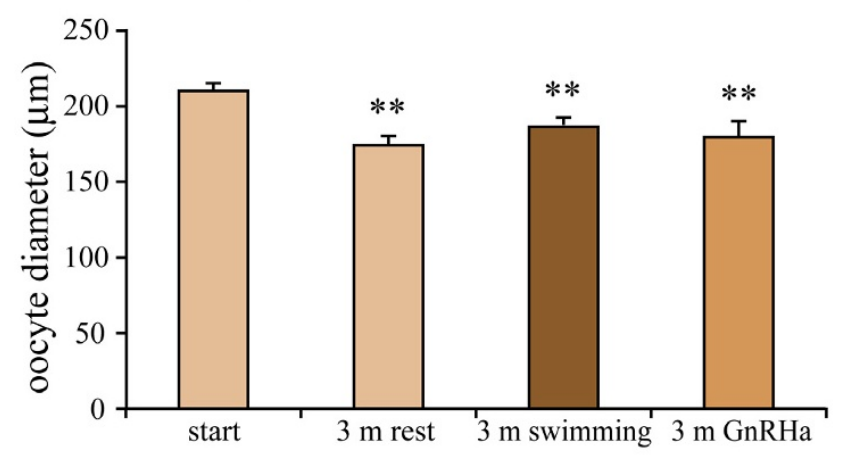

b) male testis stage

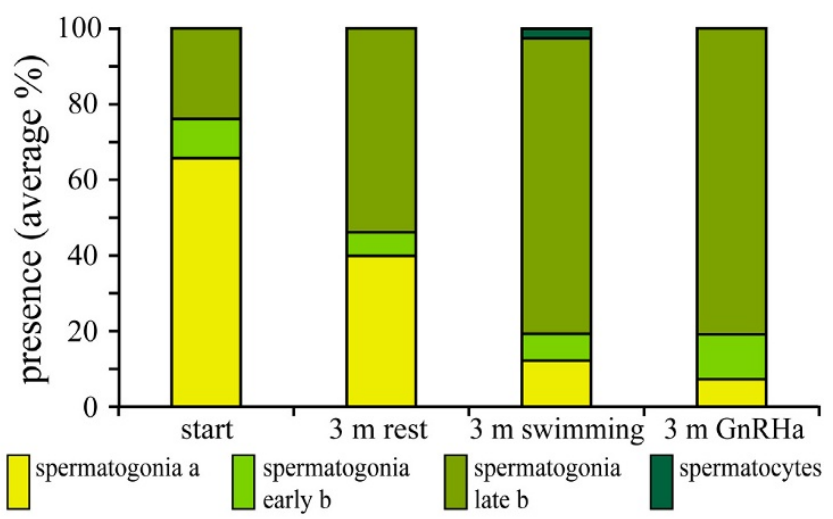

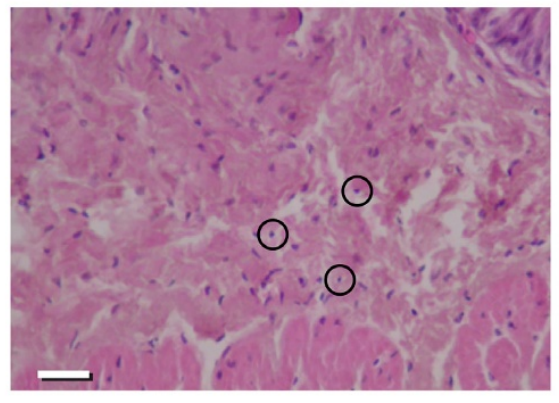

c) starter: spermatogonia a

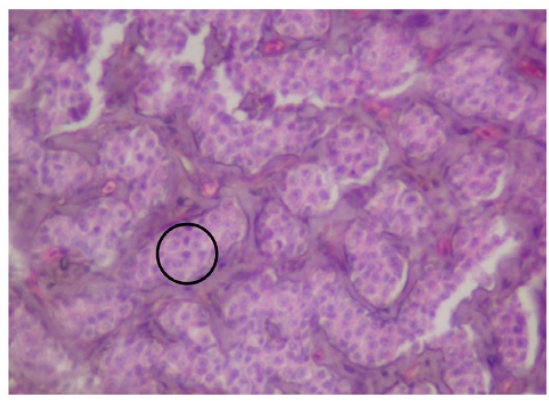

d) stimulated: spermatogonia late b

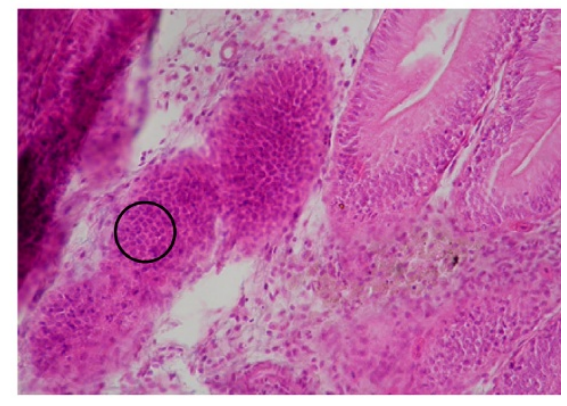

e) swimmer: spermatocytes

Figure 2

Gonad development parameters in males and females. a) oocyte diameters at the start, after 3 months of rest, after 3 months of SW-swimming and 3 months after $\mathrm{GnRHa}$ injection; b) male testis stage with frequency distribution of spermatogonia type $a$, spermatogonia early type $b$, spermatogonia late type $b$ and spermatocytes; $c$ ) testis in starter containing mainly spermatogonia type a (encircled), d) GnRH-stimulated testis containing spermatogonia late type b (encircled), e) testis of swimmer containing spermatocytes (encircled). The scale bar represents $100 \mu \mathrm{m}$. Asterisks indicate significant differences (student $\mathrm{t}$-test with $* *=\mathrm{P}<0.01 ; 3 \mathrm{~m}$ rest, $3 \mathrm{~m}$ swimming or $3 \mathrm{~m} \mathrm{GnRHa}$ vs. start).

Swimming may up-regulate GnRH-levels (in silver eels the mammalian-type GnRH - mGnRH) that subsequently leads to positive effects on LH $\beta$-production in the pituitary [8]. This action may be exerted through swimminginduced alterations in cortisol that binds to glucocorticoid receptor - expressing neurons [9]. However, in our study stimulation of LH $\beta$-expression in the pituitary only occurred in male eels. Since LH $\beta$-expression was not enhanced in females that either swam or received a GnRHa-injection, their pituitaries were considered as not sensitized and still under dopaminergic control.

As long-term swimming is required for reaching the spawning site, we conclude that swimming results in natural maturation in males, probably via the release of GnRH. Males swam in this experiment for about one sixth of their normal migration distance, so full spermiation can be expected after longer swimming trials. As naturally induced spermiation may result in improved sperm qual- ity, we expect that swimming trials will improve the success of eel breeding.

\section{Methods}

Migratory male ( $\mathrm{n}=28 ; 40 \pm 0.5 \mathrm{~cm}, 96 \pm 3 \mathrm{~g})$ and female silver eels $(\mathrm{n}=24 ; 75 \pm 1 \mathrm{~cm}, 719 \pm 38 \mathrm{~g})$ were anaesthetized, PIT-tagged (TROVAN) and randomly divided over 4 groups of $n=6$. Starters were immediately dissected $(n=$ 10 for males). Other eels either swam or rested in natural seawater $\left(35 \mathrm{ppt}, 20^{\circ} \mathrm{C}\right)$ during the experimental period of three months. Resting eels were IP injected with GnRHa ( $32 \mu \mathrm{g} / \mathrm{kg}$ Gonazon) or left untreated ('resters') in a 1,5001 tank. An oval shaped stream-gutter $\left(6.0 * 4.0^{*} 0.8 \mathrm{~m}\right.$; 6,000-1) was constructed to enable a 3 -months swimming trial. Female eels swam 1,420 km while the smaller males swam $912 \mathrm{~km}$. Pituitaries were stored in RNAlater (Ambion), mRNA was purified from these samples to quantify gene expression. 
Oligonucleotides were designed from the reported sequences of $A$. anguilla for the specific $\beta$-subunits of $\mathrm{LH}$ and FSH, and of the Japanese eel A. japonica for housekeeping gene $\beta$-actin. A specific RT-PCR was performed using RNA extracts from pituitaries from artificially matured $A$. anguilla [4]. RT-PCR was performed using the Superscript II one step RT-PCR system with platinum Taq (Invitrogen), run on the Biometra T1 Thermocycler (Westburg). The PCR products were cloned in pCRII-TOPO vector (Invitrogen), digested with restriction enzymes to identify the correct direction and sequenced (Base Clear lab services) to verify that the final products correspond to the genes of interest by aligning them to genes previously described using the VectorNTI program.

Quantitative reverse transcriptase (Q-RT) - PCR using the MasterMix for SYBR $^{\circledR}$ Green I (Eurogenetec) and the Chromo $^{\mathrm{TM}}$ Detector (Bio-Rad laboratories) was performed to quantify the expression of $\mathrm{LH} \beta, \mathrm{FSH} \beta$, and of the internal control $\beta$-actin in the pituitaries. DNA and deduced mRNA amounts were calculated from $\mathrm{Ct}$ values of standard curves generated from the plasmids containing each of the specific genes after which amounts were normalized to the expression level of the housekeeping gene $\beta$-actin.

Experiments complied with the current laws of the Netherlands and were approved by the animal experimental commission (DEC nr. 6059).

\section{Abbreviations}

FSH $\beta$ : Follicle-Stimulating Hormone $\beta$ subunit; FW: Freshwater; GnRH: Gonadotropin-Releasing Hormone; GnRHa: Gonadotropin-Releasing Hormone agonist; GSI: Gonadosomatic Index; LH $\beta$ : Luteinising Hormone $\beta$ subunit; SW: Seawater.

\section{Authors' contributions}

APP and GvdT conceived and designed the project and the experiments. APP performed the experiments, measurements, dissection and histology. DS and HPS cloned $\beta$ actin and the LH $\beta$ and FSH $\beta$ subunits and tested the right conditions for Quantitative RT-PCR. MCN performed Quantitative RT-PCR. APP and GvdT wrote the paper.

\section{Acknowledgements}

The authors wish to express their thanks to Dr W. Enright (Aquatic Animal Health Division, Intervet International BV) for providing Gonazon For Fish, to E. de Kuyper, J. Bij and P. Niemantsverdriet for their help in constructing a functional stream-gutter and the latter mentioned also for animal care, and to M. de Bakker, J. van Rijssel, V. Jacobson and R. Snepvangers for assistance with histology. M. Brittijn is acknowledged for his help with the lay-out of the figures and Dr. J. Jeffery is acknowledged for his help with the correct use of the English language. Supported by the Dutch Ministry of Agriculture, Nature and Food Quality (LNV) contract \#3201817 to GvdT.

\section{References}

I. Schmidt J: Breeding places and migration of the eel. Nature | 923, I I I:5I-54.

2. Vidal B, Pasqualini C, Le Belle N, Claire M, Holland H, Sbaihi M, Vernier $\mathrm{P}$, Zohar $\mathrm{Y}$, Dufour S: Dopamine inhibits luteinizing hormone synthesis and release in the juvenile European eel: $A$ neuroendocrine lock for the onset of puberty. Biol Reprod 2004, 7I: |49|-|500.

3. Stone R: Freshwater eels are slip-sliding away. Science 2003, 203:22I-222.

4. Palstra AP, Cohen EGH, Niemantsverdriet PRW, van Ginneken VJT, Thillart GEEJM van den: Artificial maturation and reproduction of European silver eel: Development of oocytes during final maturation. Aquaculture 2005, 249:533-547.

5. van Ginneken V, Dufour S, Sbaihi M, Balm P, Noorlander K, de Bakker M, Doornbos I, Palstra A, Antonissen E, Mayer I, Thillart G van den: Does a $5,500-\mathrm{km}$ swim trial stimulate early sexual maturation in the European eel (Anguilla anguilla L.)? Comp Biochem Physiol A 2007, 147:1095-I I03.

6. Palstra A, Curiel D, Fekkes M, de Bakker M, Székely C, van Ginneken $V$, Thillart $G$ van den: Swimming stimulates oocyte development in European eel. Aquaculture 2007, 270:32I-332.

7. Dufour S, Lopez E, Le Menn F, Le Belle N, Baloche S, Fontaine YA: Stimulation of gonadotropin release and of ovarian development, by the administration of a gonadoliberin agonist and of dopamine antagonists, in female silver eel pretreated with estradiol. Gen Comp Endocr 1988, 70:20-30.

8. Montero M, Le Belle N, King JA, Mîllar RP, Dufour S: Differential regulation of the two forms of gonadotropin-releasing hormone ( $m G n R H$ and cGnRH-II) by sex steroids in the European female silver eel (Anguilla anguilla L.). Neuroendocrinology 1995, 61:525-535.

9. Teitsma CA, Anglade I, Lethimonier C, Le Dréan G, Saliguat D, Ducouret B, Kah O: Glucocorticoid receptor immunoreactivity in neurons and pituitary cells implicated in reproductive functions in rainbow trout: A double immunohistochemical study. Biol Reprod 1999, 60:642-650.

Publish with Bio Med Central and every scientist can read your work free of charge

"BioMed Central will be the most significant development for disseminating the results of biomedical research in our lifetime. "

Sir Paul Nurse, Cancer Research UK

Your research papers will be:

- available free of charge to the entire biomedical community

- peer reviewed and published immediately upon acceptance

- cited in PubMed and archived on PubMed Central

- yours - you keep the copyright 